ACTA UNIVERSITATIS LODZIENSIS

FOLIA LITTERARIA POLONICA 4(42) 2017

http://dx.doi.org/10.18778/1505-9057.42.08

Paweł Wolski*

\title{
Resztki ciała. Cielesne doświadczenie obozowe: problemy przedstawiania
}

Cielesność w literaturze, w tym w szczególnym jej nurcie pisarstwa Zagłady, jest tematem $\mathrm{w}$ dużej mierze już omówionym ${ }^{1}$. Moim zadaniem może być więc jedynie, by tak rzec, pozbieranie po tym resztek.

Tym zaś, co pozostaje po literackim ciele w Auschwitz - Co zostaje z Auschwitz - jak powiedzieć można za Giorgio Agambenem, którego słynny tekst zamierzam, pośród innych, krótko skomentować - jest właściwie sama cielesność, taka, której zasadnicza jakość nie realizuje się w kwalifikacji genderowej, rasowej, seksualnej, chorobowej. Nie da się bowiem nie zauważyć, zerkając na książki Joan Ringelheim, Bożeny Karwowskiej, Sandera Gilmana, Dominicka LaCapry i wielu innych autorów, że aby ujrzeć ukryte w tekście ciało, żeby to ciało wyistoczyło się i nabrało kształtu, badacze czują się zmuszeni rzucać na nie, niczym na ducha - to nieprzypadkowa metafora - płachty płci, antropocentryzmu, rasistowskiej fizjonomiki itd. Ale samo ciało własnego, różnego od tych

* Dr, adiunkt; Uniwersytet Szczeciński, Instytut Polonistyki i Kulturoznawstwa; Zakład Teorii i Antropologii Literatury; Al. Piastów 40B, 71-065 Szczecin; pawel.wolski@univ.szczecin.pl.

${ }^{1}$ S. Buryła, Wokót Zagłady. Szkice o literaturze Holokaustu, Universitas, Kraków 2016 (w rozdziale Męski faszyzm autor wskazuje kilka istotnych nurtów w tym obszarze i postuluje ich rozwinięcie, wychodząc od Męskich fantazji Klausa Theweleita); S. Gilman, The Jew's body, Routledge, New York 2009; G. Agamben, Co zostaje z Auschwitz. Archiwum i świadek, przekł. S. Królak, Wydawnictwo Sic!, Warszawa 2008; A. Becker, Eksterminacje. Ciało i obozy, w: Historia ciała, t. 3: Różne spojrzenia. Wiek XX, red. J.-J. Courtine, przekł. K. Belaid i T. Stróżyński, Słowo/Obraz Terytoria, Gdańsk 2014; C.E. Forth, The Body, w: Writing the Holocaust, red. J.-M. Dreyfus i D.R. Langton, Bloomsbury Academic, London-New York 2011; B. Karwowska, Ciało, seksualność, obozy zagłady, Universitas, Kraków 2009; P. Krupiński, Ciało, historia, kultura. Pisarstwo Mariana Pankowskiego i Leo Lipskiego wobec tabu, Wydawnictwo Naukowe Uniwersytetu Szczecińskiego, Szczecin 2011; D. LaCapra, History and its limits. Human, animal, violence, Cornell University Press, Ithaca 2009; B. Przymuszała, Szukanie dotyku. Problematyka ciała w polskiej poezji współczesnej, Universitas, Kraków 2006 (nawiązania do tego tematu zawiera też książka Przymuszały: Smugi Zagłady. Emocjonalne i konwencjonalne aspekty tekstów ofiar i ich dzieci, Wydawnictwo Naukowe Uniwersytetu im. Adama Mickiewicza, Poznań 2016); K. Theweleit, Męskie fantazje, przekł. M. Falkowski i M. Herer, przekł. przejrzał A. Żychliński, Wydawnictwo Naukowe PWN, Warszawa 2015. 
prześcieradeł kształtu wciąż nie ma. Co pisząc, nie krytykuję żadnego z wymienianych autorów, bo, po pierwsze, sam taką płachtę na nie narzucam - od jakiegoś czasu analizuję obozowe narracje sportowe ${ }^{2}$, a po drugie, badane przez nas ciało i tak jest zrośnięte - $\mathrm{i}$ ta metafora nie jest przypadkowa $-\mathrm{z}$ inną jeszcze materią, wcale od tamtych nie odległą: $\mathrm{z}$ językiem.

Zrastanie się ciała z językiem ma historię zbyt długą, by ją tu śledzić - od tarć między ideą Platońską i Arystotelesowską naturą (ciekawie i w bliskim związ$\mathrm{ku}$ z poruszanymi przeze mnie dalej kwestiami literaturoznawczymi pisze o tym m.in. Michael Heath) ${ }^{3}$, przez średniowieczne debaty wokół tego, czy sens tkwi w ludzkim, karnalnym vox, czy w boskim, idealnym sermo, po nowsze pytania o granice przedstawialności doświadczenia cielesnego. Te ostatnie przyjmują czasem formę (pozornie) groteskową, np. czy Ofelia miała wszystkie zęby albo czy Sherlock Holmes miał wątrobę ${ }^{4}$ (w podobny sposób o maść konia Mazepy, a właściwie o to, czy ten koń w ogóle miał jakąś maść, pytał w Powinowactwach przez fabułę Jerzy Ziomek) $)^{5}$. Temat jest więc na tyle rozległy, że w odniesieniu do literatury Zagłady wskażę na zaledwie kilka związanych z tymi kwestiami trudności.

Pierwsza wyłania się choćby z ostatnich pytań o cielesność bohaterów Williama Shakespeara i Conana Doyle'a. Zadawanie ich w taki sposób zdaje się mocno chybione w odniesieniu do literatury Holokaustu, mimo że przytaczam je przecież za Terrym Eagletonem, autorem rozprawy o współczesnej teorii literatury - właśnie tej, której poznawcze ramy określa świat po Zagładzie, czyli po wydarzeniu, które ufundowało współczesne granice tak poznania, jak i poznawalności ciał. Bo też Eagletone nie mówi jednak o tekstowych reprezentacjach świata cielesności granicznej - takiej, w której problemem nie spekulatywnym, ale egzystencjalnym było posiadanie wszystkich zębów, obojga oczu itd. Można by wprawdzie rzec, że ten dysonans wynika z oczywistej różnicy przykładów: więźniowie opisujący obóz byli w nim naprawdę, a Sherlock Holmes nie istniał. Ripostować by jednak można mówiąc, że na podobnej zasadzie detektywi tacy

${ }^{2}$ Zob. m.in.: P. Wolski, Boks w Auschwitz. Opór ciała, w: Adlojada. Biografia i świadectwo, red. J. Brejdak, D. Kacprzak, J. Madejski, B.M. Wolska, Muzeum Narodowe, Szczecin 2014; P. Wolski, Eksces męskości. Narracje bokserskie w literaturze Zagłady, „Teksty Drugie” 2015, $\mathrm{nr}$ 2; P. Wolski, Ciało (ponownie) uprzedmiotowione. Somatyczne narracje bokserów w literaturze Zagłady i ich współczesne konteksty, w: Ślady II wojny światowej i Zagłady w najnowszej literaturze polskiej, red. B. Sienkiewicz i S. Karolak, Nauka i Innowacje, Poznań 2016; P. Wolski, „Muskeljuden" i ,Luftmenschen" na ringu. (Nie)Naturalność żydowskiego ciała atlety w literaturze obozowej, w: Natura - historia - konflikt. Artystyczne reprezentacje historii w perspektywie ekokrytyki i studiów środowiskowych, red. A. Ubertowska [i in.] (w druku).

${ }^{3}$ M. Heath, Ancient philosophical poetics, Cambridge University Press, Cambridge 2013.

${ }^{4}$ T. Eagleton, The event of literature, Yale University Press, New Haven-London 2013, s. 107.

${ }^{5}$ J. Ziomek, Powinowactwa przez fabute, w: tenże, Powinowactwa literatury. Studia i szkice, Państwowe Wydawnictwo Naukowe, Warszawa 1980, s. 86. W wywodzie Ziomka chodziło, co prawda, o adaptację filmową tekstu literackiego, ale sprawa rozbijała się $\mathrm{w}$ tym akurat przykładzie o podobne co u Eagletone'a kwestie. 
jak Holmes istnieli, a na przykład Krystian Piwowarski opisujący obóz w Więcej gazu, Kameraden! ${ }^{6}$ w nim nie był. Co jednak w ogóle nie wyjaśnia kwestii reprezentacji ciała w prozie obozowej, szczególnie zaś ciała umierającego, torturowanego lub zmarkego. $\mathrm{Z}$ etycznego, ale i narratologicznego punktu widzenia (a w przypadku narracji o Zagładzie są to porządki powiązane) sprawa jest wysoce ambiwalentna, o czym pisał Jacek Leociak (co prawda w odniesieniu do getta, nie obozu), powołując się na fragment z Państwa Platona, w którym Leontios doznaje sprzecznych uczuć na widok trupów - ,aż go żądza przemogła i wytrzeszczywszy oczy przybiegł do tych trupów i powiada: «No, macie teraz, wy moje oczy przeklęte, napaście się tym pięknym widokiem»"7. Jak zdaje się pokazywać Leociak, pomieszanie Leontiosa jest podobne do dezorientacji czytelnika tekstu (i zresztą samego autora), który doświadcza przekładu nieogarnionego, chaotycznego i niekomunikowalnego cielesnego doświadczenia tortury na uporządkowany język literatury. Ryszard Koziołek pożycza ten przykład od Leociaka (choć odrywa go od literatury Zagłady), żeby zanalizować sceny okrucieństw u Henryka Sienkiewicza jako punkty lektury abiektalnej, w których

Styl narracji nie ulega zmianie, czytelnik identyfikuje formę, jako już znaną, jednak obraz staje się nagle obcy: groźny, wstrętny, wywołujący lęk i obrzydzenie, ale właśnie radykalna obcość tego widoku sprawia, że na moment zapominamy o języku, mimo iż poza język ów horror nie wykracza ${ }^{8}$.

Sceny te stanowią więc, zdaje się mówić Koziołek, jakieś chwile epifanii: czytając je, natrafiamy na miejsce przezroczystości języka, wczuwamy się w coś, co wyrywa z kulturowego porządku (choć jednocześnie moc katarktyczna polega na tym, że można w każdym momencie i bez ryzyka do tego porządku powrócić). Koziołek czyta jednak Sienkiewicza, nam zaś cielesność pisarstwa Zagłady, w którym rozróżnienie na fikcyjność i fikcjonalność jest nieco mniej oczywiste, sprawia inny kłopot: tu, by tak rzec, prawie każda Ofelia ma wybite zęby, a większość Sherlocków Holmesów cierpi na nieustanny dyfteryt. Problem literatury w tych obszarach polega więc na czymś odwrotnym: nieprzystawaniu ,przezroczystego" języka i sygnalizowanej przezeń , już znanej” formy do opisywanej rzeczywistości. I tak też - odwrotnie - traktuje cielesność literatura Holokaustu: nie jako momenty nagle odsłaniające, ale monotonnie zasłaniające, uzwyczajniające ciało i uprzedmiotawiające jego śmierć. „Zwyczajne apokalipsy” Borowskiego są poręcznym dowodem, ale jest ich więcej. Pamiętny wezwania Arkadiusza

\footnotetext{
${ }^{6}$ K. Piwowarski, Więcej gazu, Kameraden!, Wydawnictwo W.A.B., Warszawa 2012.

${ }^{7}$ J. Leociak, Tekst wobec zagłady. O relacjach z getta warszawskiego, Wydawnictwo Naukowe Uniwersytetu Mikołaja Kopernika, Toruń 2016, s. 217.

${ }^{8}$ R. Koziołek, Ciała Sienkiewicza. Studia o płci i przemocy, Wydawnictwo Uniwersytetu Śląskiego, Katowice 2015, s. 267.
} 
Morawca, by nie pozwolić, aby Borowski zasłonił nam pozostałych autorów ${ }^{9}$, przywołam inną, charakterystyczną narrację, mniej przy tym skonstruowaną, mniej świadomą siebie, a więc łatwiej poddającą się etycznym postulatom zagładowej teorii literatury, aby traktować pisarstwo Holokaustu w kategoriach świadectwa. Czesław Jaworski we Wspomnieniach z Oświęcimia rekonstruuje długą rozmowę o warunkach życia w obozie i ontologii władzy prowadzoną w kloace tonem niemal dworskim, co robi, jak się zdaje, zupełnie bez autoironii. W pewnym momencie dostrzega jednak skatologiczne okoliczności, których kacetnik zapewne już nie zauważał i potęguje to, co dla czytelnika miało groteskowo-ironiczny wymiar od początku, a dla autobiograficznego narratora-bohatera objawia się dopiero teraz; pisze: „Czytelnik zechce mi łaskawie wybaczyć miejsce, w którym prowadziliśmy naszą «filozoficzną rozmowę», ale było to bodaj jedyne bezpieczne" ${ }^{\prime 10}$. Jest to właśnie taki moment literackiej cielesności na opak: miast szokować cielesnym naturalizmem, Jaworski szokuje nieprzystojnym w okolicznościach obozowych gestem kurtuazji; epifania nie kryje się więc w przezroczystości języka, ale w przezroczystości transcendującej go przemocy.

Język sprawia jednak również kłopot, gdy podchodzić do niego od drugiej strony, tzn. wówczas, gdy traktujemy go, jak ja przed chwilą, nazbyt podejrzliwie. Do dziś śmieszy nas lub oburza, tak jak śmieszyło i oburzało w kolejnych odsłonach polemiki między Tadeuszem Borowskim i Zofią Kossak, gdy czytamy w jej oświęcimskich wspomnieniach $Z$ otchłani, jak to Polki-katoliczki znacznie lepiej znosiły obozowy głód dzięki tradycji kościelnej przygotowującej do postu $^{11}$. Ale już z powagą czytamy słowa Primo Leviego, który swoje przetrwanie chce zawdzięczać m.in. przedwojennym wycieczkom w góry, długim marszom, którym również towarzyszyły okresy przymusowego głodowania ${ }^{12}$. Niezależnie od tego, czy dystansujemy się od języka Kossak ze względu na jego zakrawający na bigoterię styl (znacznie, zauważmy, złagodzony w drugiej wersji książki, będącej, jak dowodzi nieoceniony komentator tej polemiki Dariusz Kulesza, jedyną ripostą na atak Borowskiego) ${ }^{13}$ albo czy damy się uwieść pozornie unaukowionej narracji Leviego, sprawa rozbija się o to, że literatura Zagłady przedkłada pewne

\footnotetext{
${ }^{9}$ A. Morawiec, Literatura $w$ lagrze, lager w literaturze. Fakt, temat, metafora, Wydawnictwo Akademii Humanistyczno-Ekonomicznej, Łódź 2009.

${ }^{10}$ C.W. Jaworski, Wspomnienia z Oświęcimia, Instytut Wydawniczy Pax, Warszawa 1962, s. 101.

${ }^{11}$ Z. Kossak, Z otchłani. Wspomnienia z lagru, Wydawnictwo Księgarni Wł. Nagłowskiego, Częstochowa-Poznań 1947, s. 55. Tadeusz Borowski ten fragment krytykował w Alicji w krainie czarów, artykule, który w najnowszym wydaniu znaleźć można w: T. Borowski, Pisma w czterech tomach, red. T. Drewnowski, J. Szczęsna i S. Buryła, Wydawnictwo Literackie, Kraków 2005, t. 4: Krytyka, s. 80.

${ }_{12}$ Opowiadał o tym m.in. w utworze Żelazo, w: P. Levi, Układ okresowy, przekł. Z. Koprowska, Wydawnictwo Literackie, Kraków 2011, s. 58-76.

${ }^{13}$ D. Kulesza, Dwie prawdy. Zofia Kossak i Tadeusz Borowski wobec obrazu wojny w polskiej prozie lat 1944-1948, Trans Humana, Białystok 2006.
} 
konwencje nad inne. Mistycyzm, być może szczególnie mistycyzm niejudaistyczny, znajduje się dziś daleko na liście preferowanych stylów wypowiedzi, zaś pozornie chłodne sprawozdawstwo o wiele bliżej. I choć można się spierać, czy głód w ogóle może ulegać wpływowi kultury na zasadzie technik cielesnych takich jak pozycje porodu opisywane przez Marcela Maussa ${ }^{14}$ (wymieniającego społeczności, dla których naturalny jest np. poród siedzący, stojący itd.), czy też jest to kompletnie niezależne od rasy, kultury, klimatu itd. zdarzenie fizjologiczne, które po równo wyniszcza organizm wprawiony i niewprawiony, to spór ten i tak nie dochodzi do głosu wówczas, gdy hipotezy antropologiczne Kossak a priori przegrywają z równie nieweryfikowalną fizjologiczną autodiagnozą Leviego. W efekcie zaś pod genderowo-etniczną płachtą (narzuconą na skądinąd rzeczywiście szowinistyczną perspektywę Zofii Kossak) gubi się podstawowa prawda ciała znana nie tylko teoretykom sportu, ale i epigenetykom (o których wspomnę jeszcze za chwilę): że ciało można rzeczywiście ćwiczyć, być może nawet tak, by zmieniać jego jakoby „wrodzone” predyspozycje.

Gdy mowa o konwencjach bliskich lub dalekich modelowym narracjom o Zagładzie, trzeba też wspomnieć krótko psychoanalizę, która na długo zdominowała akademickie mówienie o Holokauście. Warto pamiętać, że był to nurt rewolucyjny przede wszystkim o tyle, o ile dowodził istnienia traum innych, niż tylko widoczne na ciele. Ale, jak twierdzi Sander Gilman ${ }^{15}$, jego wersję „,narracyjną", tzn. skupiającą się na mowie pacjenta (jego opowieści o marzeniach sennych i dzieciństwie, oczywiście wespół z patologiami zdolności mowy i dopiero następnie innymi patologiami cielesnymi, takimi jak nerwowe tiki), wypracował Freud w reakcji na teorie swojego nauczyciela Jeana-Martina Charcota, którego bardziej interesowały odruchy i wygląd ciała pacjenta, niż jego opowieść. Charcot był antysemitą, doszukującym się m.in. wrodzonych patologii w ciele Żyda i być może dlatego, jak przypuszcza Gilman, Freud zmodyfikował wzięte od niego nauki tak, by ciało przestało być stygmatem; przeniósł więc te stygmaty w niemanifestujące się na pierwszy rzut oka miejsca „niewidoczne”, z których trzeba je dopiero wydobywać podczas terapii - czyli rozmowy. W literaturoznawstwie Zagłady dominuje właśnie ten wzorzec, stawiający ucho wyżej oka, czyli koherentną i logiczną narrację emocjonalnemu obrazowi (notabene: w układzie uderzająco podobnym do wcześniej wspomnianego sporu o vox i sermo). Choć bowiem wiele rozpraw i nurtów mocno wpływających na stosowane w jego ramach praktyki (np. klasyczna książka Shoshany Felman i Doriego Lauba ${ }^{16}$ albo teoria post-traumy - obie wyrastające zresztą z psychoanalizy), deklaruje zainteresowanie tym,

\footnotetext{
${ }^{14}$ M. Mauss, Sposoby postugiwania się ciatem, w: Socjologia i antropologia, przekł. M. Król, K. Pomian i J. Szacki, Państwowe Wydawnictwo Naukowe, Warszawa 1978.

${ }^{15}$ S. Gilman, dz. cyt., s. 55 i n.

${ }^{16}$ S. Felman, D. Laub, Testimony. Crises of witnessing in literature, psychoanalysis, and history, Routledge, New York-London 1992.
} 
co chaotyczne i emocjonalne, a więc np. odsłaniające się w przelotnym geście ciała, to obiektem badań w każdym przypadku pozostaje racjonalna i koherentna narracja słowna. A jednak pewne wątki badań nad traumą pojawiające się w ramach Holocaust studies dziś, pomagają uwyraźnić obecny w nich wprawdzie i nieodzowny, acz skryty wymiar cielesny świadka. Pisze o tym Anna Artwińska (w odniesieniu do Małej Zagłady Janko):

W interpretacji Anny Janko język ciała drugiego i trzeciego pokolenia komunikuje mutacje genów, które dokonały się w ciele pierwszego pokolenia pod wpływem traumatycznego wydarzenia [...]. Jest to o tyle ciekawe, że narratorka wyraźnie podkreśla zależność własnych reakcji somatycznych od otoczenia: mianowicie, uaktywniają się one przede wszystkim na Zamojszczyźnie; są czymś w rodzaju uczulenia czy alergii kontaktowej na ,ziemię przodków"17.

Obok pozytywnych przykładów cielesności od dawna fundującej nasze mówienie o Zagładzie chcę na koniec zatrzymać się na tym, który dał podtytuł mojemu wystąpieniu i który będzie, jak zapowiadałem, przykładem negatywnym. Propozycje Agambena o muzułmanie jako świadku modelowym można sprowadzić, w interesującym mnie kontekście, do tezy, że w ciele tego umarłego za życia tli się już tylko gotowe do zgaśnięcia dzoe, życie biologiczne, brak w nim tego, co społeczne, co ludzkie - bios. Nie biorę udziału w chyba już przebrzmiałej polemice wokół Agambena, ale używam jego koncepcji, żeby pokazać pewien nurt w badaniu Zagłady, który mimo niewątpliwych zalet zakrywa i samą Zagładę, i jej realny, cielesny wymiar. Problemem jest przede wszystkim oparcie się na binarnym kodowaniu cielesności. Agambenowski koncept jest oczywiście przekonujący i świetnie obrazuje postkapitalistyczną tanatopolitykę, ale najzwyczajniej nie zgadza się z obozową rzeczywistością (chyba w tym zresztą tkwi jego uwodzicielska moc - więcej mówi o naszej wizji obozu niż o obozie samym). Jak pokazała Ewa Domańska $^{18}$, Agamben, wbrew własnym zastrzeżeniom, hipostazuje muzułmana jako aporię, a w ostatecznym rozrachunku epifanię Auschwitz w sensie pozytywnym jako udany wytwór biopolityki, przemycając założenie, że człowieczeństwo to jakość kulturowa, a zatem kontyngentna - i że można człowiekowi nie tylko ją odebrać względnie prostymi środkami, ale zarządzać nią tak, by nieumarły i nie

${ }^{17}$ A. Artwińska, Transfer międzypokoleniowy, epigenetyka $i$,więzy krwi”. O „,Małej Zagładzie” Anny Janko i „Granicy zapomnienia” Siergieja Lebiediewa, „Teksty Drugie” 2016, nr 1, s. $120-121$.

18 ,[...] filozofczne refleksje autorów niemających bezpośredniego doświadczenia obozowego przenoszą je w sferę filozoficznych spekulacji, w której muzułman jako uniwersalizująca figura znajdującego się w sytuacji ekstremalnej człowieka staje się instrumentem uwierzytelniającym teoretyczną koncepcję działania obozowej machiny jako elementu biowładzy" (E. Domańska, Muzulman: świadectwo i figura, w: Zagłada. Wspótczesne problemy rozumienia i przedstawiania, red. P. Czapliński, E. Domańska, Wydawnictwo Poznańskie Studia Polonistyczne, Poznań 2009, s. 69). 
żywy nie mógł dysponować ani swym życiem, ani śmiercią. Liczne lektury narracji obozowych pokazują jednak możliwość kodowania człowieczeństwa jako wartości biologicznej, a zatem niezbywalnej w tym sensie, że odebrać ją można jedynie wraz z życiem. Piszący w czasach nieodległych od wydarzenia Zagłady Żydów autorzy tacy jak Bruno Bettelheim ${ }^{19}$ czy Michał Borwicz ${ }^{20}$, dążący do rewindykacji ludzkiej godności w obliczu dehumanizujących warunków w obozach, gettach itd., umocnili taki paradygmat czytania narracji o przetrwaniu, w którym to, co wzniosłe, intelektualne, pozwalało przetrwać ciału poddanemu warunkom niewystarczającym do przeżycia w sensie biologicznym (symbolem tego układu może być zawołanie ,puść palce”, pojawiające się w narracji Zofii Romanowiczo$w^{21}{ }^{21}$ zawsze wtedy, gdy bliska zmuzułmanienia narratorka stała na progu oddania się, kosztem godności, somatycznej żądzy głodu). I było tak bez wątpienia, problem jednak nie w tym, czy miłość, religia, wiara, poezja były ważniejsze niż jedzenie, spanie, wydalanie, ale czy to rozróżnienie dziś jest jedynym możliwym albo chociaż, czy hierarchia jego członów musi zakładać, by tak rzec, taką właśnie intelektualną bazę cielesnej nadbudowy. Bo na przykład Jean Améry pisze o zupełnie odwrotnym kierunku wychodzenia ze stanu zmuzułmanienia:

Przypominam sobie, jak pewnego razu pielęgniarz z któregoś ze szpitalnych baraków ofiarował mi talerz słodzonego grysiku, który pochłonąłem łapczywie, wpadając w stan nadzwyczajnej euforii umysłu. [...] Owładnęło mną szaleńcze pragnienie intelektualnych doznań [...]; moja świadomość chaotycznie napełniła się po brzegi strzępami różnych książek, okruchami zasłyszanej muzyki, własnymi, jak mi się wydawało, filozoficznymi myślami²2.

To soma wywołała w nim potrzebę semy. Ująć by to można jeszcze tak: nie duch ozdrowił ciało, ale dopiero ciało powołało ducha. Nie w hierarchii takich binarnych instancji jednak rzecz, lecz w tym, że „muzułman” to właśnie nie ciało pozbawione ducha ani duch obleczony w martwe ciało, ale raczej ciało pozbawione swojej cielesności, tego, co jest jej realnym wymiarem w sensie die Handarbeit Sohn-Rethela ${ }^{23}$. Na pozór różnica jest nazbyt subtelna: co Sohn-Rethel nazwałby

${ }^{19}$ B. Bettelheim, Individual and Mass Behavior in Extreme Situations, „The Journal of Abnormal and Social Psychology" 1943, nr 38 oraz, przede wszystkim: tenże, The Informed Heart: Autonomy in a Mass Age, Free Press, Glencoe 1960.

${ }^{20}$ Np. M.M. Borwicz, Literatura w obozie, Wojewódzka Żydowska Komisja Historyczna, Kraków 1946.

${ }^{21}$ Z. Romanowiczowa, Przejście przez Morze Czerwone, Libella, Paryż 1960, s. 60.

22 J. Améry, Poza wina i kara. Próby przełamania podjęte przez złamanego, przekł. R. Turczyn, Homini, Kraków 2007, s. 39.

${ }^{23}$ A. Sohn-Rethel, Geistige und körperliche Arbeit. Zur Theorie der gesellschaftlichen Synthesis, Suhrkamp, Frankfurt am Main 1973 (fragment w języku polskim znaleźć można w: A. Sohn-Rethel, Forma towaru i forma myśli - krytyka teorii poznania, przekł. M. Ratajczak, w: Ekonomia 
odjęciem wymiaru realnego z abstrakcyjnej intelektualnej zdolności człowieka, Agamben nazywa po prostu pozbawieniem dzoe jego bios. W rzeczywistości jednak subtelność terminologiczna sygnalizuje ważną zasadę: nagie życie muzułmana nie jest biopolitycznie obnażone dlatego, że zabrano mu zdolność myślenia o pięknie, czyli funkcjonowanie w sferze bios, ale dlatego, że zabrano mu właśnie to, co jako dzoe warunkuje bios i jest jego częścią: kalorie, ubranie i chodaki, że uczyniono jego wzrok mętnym, a chód nienaturalnym. Agamben sugeruje, że odzierając dzoe z kolejnych warstw otaczającego je intelektualnego życia Niemcy dotarli do najprawdziwszej, obnażonej biologii, czyli tego, co w człowieku najgłębsze i może nawet najprawdziwsze, choć nieświadome. Narracje Zagłady pokazują zaś, że powrotna droga do świadomości tego, co ludzkie, a zatem do życia nie nagiego i nie wystawionego na rządy biowładzy, nie musi prowadzić jedynie przez poezję i pragnienie piękna, ale może też, a może właśnie musi przez cieplejsze ubranie, krzepiący sen, pasujące obuwie lub słodki grysik.

Z przyjęcia takiej perspektywy, odwrotnej wobec Agambenowskiej, a wydobywającej w mówieniu o literaturze Zagłady to, co w niej i tak jest, wynikają określone konsekwencje. Na przykład uprawomocniają mówienie o reżimie cielesnym jako formie oporu (tak pisze o tym wymieniona wcześniej w przypisie Anette Becker) albo kierują uwagę na paradoks zaobserwowany już przez Gregoire'a Chameyeu w odniesieniu do niewolnictwa dziewiętnastowiecznego: medyczne eksperymenty na więźniach uznawanych w systemie wartości eksperymentatorów za nie-ludzi stanowią swoiste zwycięstwo cielesności nad budowanymi na jej kanwie ideologiami - skoro robimy eksperymenty na ciałach podłych, jak je nazywa Chamayeu, po to, by leczyć nasze, szlachetne ciała, to jednak uznajemy, że ciała podłe od szlachetnych wcale tak wiele nie różni ${ }^{24}$ (wspomniana zależność i jej komplikacje ciekawie rysują się w Lekcji anatomii doktora D. Leszka Engelkinga) ${ }^{25}$.

Ciało, jak starałem się pokazać, w narracjach o Zagładzie jest obecne od dawna zarówno w dyskursie intymistycznym (jak u Jaworskiego), jak i fikcjonalnym, a nawet fikcyjnym (jak u Borowskiego) czy akademickim (jak w procesie badawczej legitymizacji traumy przenoszonej na drugie, trzecie pokolenia). Bo i świadectwo jako zasadnicza modalność tej literatury od początku domaga się uznania cielesności świadka za zasadniczy jej wyznacznik. Co prawda modalność

literatury. Antologia, red. P. Tomczok, M. Ratajczak, Wydawnictwo Uniwersytetu Śląskiego, ULUCZ, Katowice 2017).

${ }^{24}$ G. Chamayou, Podte ciała. Eksperymenty na ludziach w XVIII i XIX wieku, przekł. J. Bodzińska i K. Thiel-Jańczuk, Słowo/Obraz Terytoria, Gdańsk 2012, s. 282-283.

${ }^{25}$ L. Engelking, Lekcje anatomii doktora D., Wydawnictwo Literackie, Kraków 2016. 
ta obejmuje też pozornie sprzeczny wobec tamtej okoliczności postulat obiektywizmu, stanowi więc pozornie nieprawdopodobną, a z pewnością paradoksalną mieszankę cielesnego bycia w samym środku chaosu wydarzeń i zarazem bezcielesnego, bezperspektywistycznego spoglądania nań z zewnątrz, a mimo to ciało stanowi ukryty, by tak rzec - podskórny nurt literatury Zagłady i jej akademickich komentarzy. Gdy więc w ramach tej części akademickiej dyskusji mówimy - w zasadzie od niedawna - o ciele konkretnym: kobiecym, żydowskim, homoerotycznym albo sportowym, to nie tyle mówimy coś nowego, lepszego, ile właściwe obnażamy inherentną niemoc dyskursu cielesnego. Jest to niemoc, którą na różne sposoby wyrażali już Maurice Merleau-Ponty, Arthur Danto ${ }^{26}$ i inni: cały kłopot, powiadają, sprowadza się do tego, że nie jesteśmy w naszych ciałach, ale jesteśmy naszymi ciałami i gdy chcemy ujrzeć nasze ciała z zewnątrz, pozbawiamy się podstawowego narzędzia propriocepcyjnego - czyli właśnie ciała. Także w literaturze, także gdy chodzi o ciała poddane okrucieństwom, a więc właściwie wyeksponowane w bólu. Powołam się jeszcze raz na Koziołka:

[Abiektalna moc scen okrucieństwa sprawia, że] Narracja sięga po inne środki, między innymi po metafory, które ideologizują konflikt. Chodzi tu przede wszystkim o substytucje, poprzez które w miejsce ciała ludzkiego zostaje podstawiony np. obraz zwierzęcia. Obraz konkretnego (własnego) ciała zostaje odsunięty sprzed oczu czytelnika, a w to miejsce podstawiona zostaje metafora (płynna masa, fala, zboże, trawa, robactwo, itp. $)^{27}$.

I waśnie żeby uciec przed metaforyzacją ciała, sięgamy po jego konkretne, rzeczywiste, jak nam się zdaje, wymiary, takie jak wspomniana kobiecość itp., które jednak w literaturze muszą być kodowane w znakach z ciałem nietożsamych. Co zauważywszy, sięgamy po kolejne narzędzia obiecujące wyjście z zaklętego kręgu: doświadczenie, afekty, postzależność, ekonomię literatury, posthumanizm, sport. Nie ma w nich jednak chyba niczego, co narusza etyczne granice mówienia o tym doświadczeniu; o ile, inaczej niż w przypadku Agambena, trzymać się zapisanego w literaturze Zagłady konkretu obozowej rzeczywistości.

\footnotetext{
${ }^{26}$ Mam przede wszystkim na myśli: M. Merleau-Ponty, Fenomenologia percepcji. Fragmenty, przekł. J. Migasiński i P. Stefańczyk, Wydawnictwo IFiS PAN, Warszawa 1993, oraz niektóre z esejów zamieszczonych w A.C. Danto, The body/body problem selected essays, University of California Press, Berkeley 1999.

${ }^{27}$ R. Koziołek, dz. cyt., s. 274-275. Notabene chyba niezamierzenie Koziołek wymienia metafory, zdaniem wspomnianego wcześniej Theweleita, najistotniejsze dla autoidentyfikacji ciała faszystowskiego.
} 


\section{Bibliografia}

Agamben Giorgio, Co zostaje z Auschwitz. Archiwum i świadek, przekł. Sławomir Królak, Wydawnictwo Sic!, Warszawa 2008.

Améry Jean, Poza wina i kara próby przełamania podjęte przez złamanego, przekł. Ryszard Turczyn, Homini, Kraków 2007.

Artwińska Anna, Transfer międzypokoleniowy, epigenetyka i „więzy krwi”. O „Małej Zagładzie” Anny Janko i ,Granicy zapomnienia” Siergieja Lebiediewa, „Teksty Drugie” 2016, nr 1, s. 13-29.

Becker Anette, Eksterminacje. Ciało i obozy, w: Historia ciała, red. Jean-Jacques Courtine, przekł. Krystyna Belaid i Tomasz Stróżyński, Słowo/Obraz Terytoria, Gdańsk 2014, t. 3: Różne spojrzenia. Wiek XX, s. 299-316.

Bettelheim Bruno, Individual and Mass Behavior in Extreme Situations, „The Journal of Abnormal and Social Psychology" 1943, nr 38, s. 417-452.

Bettelheim Bruno, The Informed Heart: Autonomy in a Mass Age, Free Press, Glencoe 1960.

Borowski Tadeusz, Pisma w czterech tomach, red. Tadeusz Drewnowski, Joanna Szczęsna, Sławomir Buryła, Wydawnictwo Literackie, Kraków 2005, t. 4: Krytyka.

Borwicz Michał Maksymilian, Literatura w obozie, Wojewódzka Żydowska Komisja Historyczna, Kraków 1946.

Buryła Sławomir, Wokót Zagłady. Szkice o literaturze Holokaustu, Universitas, Kraków 2016.

Chamayou Gregoire, Podte ciała. Eksperymenty na ludziach w XVIII i XIX wieku, przekł. Jadwiga Bodzińska i Katarzyna Thiel-Jańczuk, Słowo/Obraz Terytoria, Gdańsk 2012.

Danto Arthur C., The body/body problem selected essays, University of California Press, Berkeley 1999.

Domańska Ewa, Muzułman: świadectwo i figura, w: Zagłada. Współczesne problemy rozumienia i przedstawiania, red. Przemysław Czapliński, Ewa Domańska, Poznańskie Studia Polonistyczne, Poznań 2009.

Eagleton Terry, The event of literature, Yale University Press, New Haven-London 2013.

Engelking Leszek, Lekcje anatomii doktora D., Wydawnictwo Literackie, Kraków 2016.

Felman Shoshana, Laub Dori, Testimony. Crises of witnessing in literature, psychoanalysis, and history, Routledge, New York-London 1992.

Forth Chrisopher E., The Body, w: Writing the Holocaust, red. Jean-Marc Dreyfus i Daniel R. Langton, Bloomsbury Academic, London-New York 2011.

Gilman Sander, The Jew's body, Routledge, New York 2009.

Heath Malcolm, Ancient philosophical poetics, Cambridge University Press, Cambridge 2013.

Jaworski Czesław W., Wspomnienia z Oświęcimia, Instytut Wydawniczy Pax, Warszawa 1962.

Karwowska Bożena, Ciało, seksualność, obozy zagłady, Universitas, Kraków 2009.

Kossak Zofia, Z otchłani. Wspomnienia z lagru, Wydawnictwo Księgarni Wł. Nagłowskiego, Poznań 1947.

Koziołek Ryszard, Ciała Sienkiewicza. Studia o ptci i przemocy, Wydawnictwo Uniwersytetu Śląskiego, Katowice 2015.

Krupiński Piotr, Ciało, historia, kultura. Pisarstwo Mariana Pankowskiego i Leo Lipskiego wobec tabu, Wydawnictwo Naukowe Uniwersytetu Szczecińskiego, Szczecin 2011.

Kulesza Dariusz, Dwie prawdy. Zofia Kossak i Tadeusz Borowski wobec obrazu wojny w polskiej prozie lat 1944-1948, Trans Humana, Białystok 2006.

LaCapra Dominick, History and its limits. Human, animal, violence, Cornell University Press, Ithaca 2009. 
Leociak Jacek, Tekst wobec zagłady. O relacjach z getta warszawskiego, Wydawnictwo Naukowe Uniwersytetu Mikołaja Kopernika, Torun 2016.

Levi Primo, Żelazo, w: Levi Primo, Układ okresowy, przekł. Zofia Koprowska, Wydawnictwo Literackie, Kraków 2011.

Mauss Marcel, Sposoby postugiwania się ciałem, w: Socjologia i antropologia, przekł. Marcin Król, Krzysztof Pomian, Jerzy Szacki, Państwowe Wydawnictwo Naukowe, Warszawa 1978.

Merleau-Ponty Maurice, Fenomenologia percepcji. Fragmenty, przekł. Jacek Migasiński i Piotr Stefańczyk, Wydawnictwo IFiS PAN, Warszawa 1993.

Morawiec Arkadiusz, Literatura $w$ lagrze, lager $w$ literaturze. Fakt, temat, metafora, Wydawnictwo Akademii Humanistyczno-Ekonomicznej, Łódź 2009.

Piwowarski Krystian, Więcej gazu, Kameraden!, Wydawnictwo W.A.B., Warszawa 2012.

Przymuszała Beata, Smugi Zagłady. Emocjonalne i konwencjonalne aspekty tekstów ofiar i ich dzieci, Wydawnictwo Naukowe Uniwersytetu im. Adama Mickiewicza, Poznań 2016.

Przymuszała Beata, Szukanie dotyku. Problematyka ciała w polskiej poezji współczesnej, Universitas, Kraków 2006.

Romanowiczowa Zofia, Przejście przez Morze Czerwone, Libella, Paryż 1960.

Sohn-Rethel Alfred, Geistige und körperliche Arbeit. Zur Theorie der gesellschaftlichen Synthesis, Suhrkamp, Frankfurt am Main 1973.

Theweleit Klaus, Męskie fantazje, przekł. Mateusz Falkowski i Michał Herer, przekł. przejrzał Arkadiusz Żychliński, Wydawnictwo Naukowe PWN, Warszawa 2015.

Wolski Paweł, Boks w Auschwitz. Opór ciała, w: Adlojada. Biografia i świadectwo, red. Jaromir Brejdak, Dariusz Kacprzak, Jerzy Madejski, Beata Małgorzata Wolska, Muzeum Narodowe, Szczecin 2014.

Wolski Paweł, Ciało (ponownie) uprzedmiotowione. Somatyczne narracje bokserów w literaturze Zagłady i ich współczesne konteksty, w: Ślady II wojny światowej i Zagłady w najnowszej literaturze polskiej, red. Barbara Sienkiewicz i Sylwia Karolak, Nauka i Innowacje, Poznań 2016.

Wolski Paweł, Eksces męskości. Narracje bokserskie w literaturze Zagłady, „Teksty Drugie” 2015, nr 2, s. 180-202.

Ziomek Jerzy, Powinowactwa przez fabułe, w: Ziomek Jerzy, Powinowactwa literatury. Studia i szkice, Państwowe Wydawnictwo Naukowe, Warszawa 1980.

Paweł Wolski

\section{Remnants of The Body. On The Representation of Somatic Experience of The Holocaust}

(Summary)

The author comments on some fundamental issues connected to the representation of the bodily experience within Holocaust literature as a particular kind of writing based on two paradigms: the ethical one, blurring common definitions of fiction and fictionality (including the definition of somatic reality in autobiographical, quasi-autobiographical and fictional Holocaust narratives), and the body-mind one, funding the discourse of dignity within the death camps 
(intellectual resistance being presented as the only possible one within the sub-human treatment of the body). The author, while recognizing validity of both, demands a recognition of bodily aspects of Holocaust literature. He does so by using the example of well-known critical comments on Giorgio Agamben's theory of ,the Muselman”.

Keywords: holocaust literature; somatocritics; bodily experience; Muselman; Giorgio Agamaben 